\title{
Pemenuhan Rumah Layak Huni di Provinsi Riau
}

\author{
Tiar Pandapotan $\mathrm{Purba}^{1}$, dan Topan Himawan ${ }^{2}$ \\ ${ }^{1}$ Mahasiswa Sekolah Pascasarjana PWK Universitas Pakuan, ${ }^{2}$ Ahli Madya PWK \\ e-mail: tiar.poerba@gmail.com
}

\begin{abstract}
Abstrak-Rumah layak huni merupakan kebutuhan dasar manusia untuk memperoleh kehidupan yang lebih baik. Penelitian ini bertujuan untuk mengetahui strategi pemenuhan hak rumah layak huni di Provinsi Riau. Penelitian yang digunakan melalui pendekatan studi kasus (case study approach). Rancangan penelitian yaitu penelitian eksplanatori. Penelitian ini dilakukan pada bulan September sampai Desember 2019 di Provinsi Riau. Data yang dikumpulkan dalam penelitian ini terdiri atas data primer dan sekunder dengan melalui observasi, wawancara terstruktur, Focus Group Discussion (FGD) dan metode pustaka. Analisis proyeksi penduduk menggunakan metode pertumbuhan penduduk eksponensial. Hasil penelitian dianalisis secara analisis deskriptif yaitu digambarkan melalui data. Sementara analisis pencarian perumahan dan permukiman yang berada di kawasan bukan untuk fungsi permukiman menggunakan pendekatan sistem informasi geografi atau Geographic Information System (GIS) dengan melakukan proses tumpang tindih (overlay). Pemenuhan hak rumah layak huni di Provinsi Riau sangat progresif, mengingat jumlah masyarakat miskin dan belum memiliki rumah sebanyak 314.692 rumah tangga (RT) dan berpotensi bertambah, selain itu terdapat perumahan/permukiman yang berada diluar fungsi hunian seperti di kawasan hutan lindung, gambut, sempadan sungai dan pantai yang menjadi perhatian pemerintah daerah, oleh karenanya melalui Program Pembangunan Rumah Sederhana Layak Huni (RSLH), Pemerintah Daerah Provinsi Riau memenuhi kewajiban layanan dasar agar masyarakat miskin dapat tertolong dari jurang kemiskinan.
\end{abstract}

Kata Kunci-Backlog, Rumah, Sederhana, Layak, Huni

\section{PENDAHULUAN}

$\mathrm{P}$ erumahan dan permukiman dan permukiman merupakan salah satu kebutuhan dasar bagi manusia yang mempunyai peran penting dalam peningkatan kualitas sumber daya manusia (SDM). Upaya yang dilakukan dalam menyelesaikan permasalahan penduduk yang kurang mampu dalaam materi adalah pemenuhan hak dasar penduduk seperti pemenuhan pangan, layanan kesehatan, layanan pendidikan, pekerjaan dan berusaha, air bersih, dan sanitasi serta hak pemenuhan tempat tinggal. Perumahan adalah salah satu kebutuhan dasar yang sulit dimiliki oleh masyarakat miskin di Indonesia [1].

Semua orang memiliki hak untuk hidup sejahtera lahir dan batin, bertempat tinggal, dan mendapatkan lingkungan hidup yang nyaman dan sehat, hal ini merupakan kebutuhan dasar manusia dan mempunyai peran penting dalam pembentukan watak atau kepribadian bangsa sebagai salah satu hal pokok yang membentuk masyarakat Indonesia seutuhnya, berjati diri, mandiri, dan produktif [2].
Selanjutnya didalam UU No 23 Tahun 2014 tentang Pemerintahan Daerah pada pasal 12 tertulis urusan perumahan dan kawasan permukiman merupakan urusan wajib pelayanan dasar yang selanjutnya harus dituangkan dalam Anggaran Pendapatan Belanja Daerah .

Peraturan Daerah Nomor 16 Tahun 2018 yang berisi Penyelenggaraan Perumahan dan Kawasan Permukiman pada pasal 6 huruf (i) menjelaskan salah satu tugas pemerintah provinsi adalah memfasilitasi penyediaan perumahan dan kawasan permukiman bagi masyarakat, terutama bagi rumah tangga miskin, masyarakat berpenghasilan rendah, masyarakat yang terkena relokasi akibat program pemerintah dan korban bencana, Aparatur Sipil Negara golongan I, II, dan III.

Sebagaimana diketahui bahwa jumlah penduduk Provinsi Riau pada tahun 2018 mencapai 6.904.910 jiwa, dimana porsi jumlah terbesar berada di Pekanbaru, Kampar dan Indragiri Hilir. Sementara jumlah orang miskin 494.300 jiwa pada tahun itu. Berdasarkan data yang dikeluarkan oleh Badan Kependudukan dan Keluarga Berencana Nasional (BKKBN) Provinsi Riau tahun 2016 tertulis terdapat 314.692 rumah tangga miskin yang belum memiliki rumah (dikenal dengan backlog) dan memerlukan perhatian Pemerintah Provinsi [4]. Backlog perumahan secara umum diartikan sebagai kondisi kesenjangan antara jumlah rumah terbangun dengan jumlah rumah yang dibutuhkan oleh rakyat. Dari pengertian ini, backlog perumahan adalah sejumlah rumah yang belum/tidak tertangani. Backlog perumahan dihitung berdasarkan konsep bahwa satu rumah tangga atau kepala keluarga hanya memerlukan satu perumahan. Terdapat pendapat lain yang mengatakan bahwa backlog perumahan adalah sejumlah akumulasi terhadap rumah tangga yang tinggal di rumah tidak layak huni.

\section{METODOLOGI}

Pendekatan studi kasus (case study approach) adalah metode yang digunakan dalam penelitian ini. Rancangan penelitian yang digunakan yaitu penelitian eksplanatori. Penelitian ini dilakukan di Provinsi Riau di bulan September hingga Desember 2019.

Data dalam penelitian ini terdiri dari data primer dan sekunder hasil observasi, wawancara terstruktur, Focus Group Discussion (FGD) dan metode studi pustaka. Analisis proyeksi penduduk memakai metode pertumbuhan penduduk eksponensial. Hasil dari penelitian ini dianalisis menggunakan analisis deskriptif. Sedangkan analisis sistem informasi geografi atau Geographic Information System dengan 
melakukan proses tumpang tindih (overlay) yang hasilnya akan menjadi informasi keruangan wilayah terkait dengan keberadaan sebaran hunian masyarakat di kabupaten/kota yang ada.

Sementara perhitungan backlog menggunakan rumusan model bahwa kuantitas rumah yang belum/tidak tertangani [8].

\section{HASIL DAN DISKUSI}

\section{A. Kebijakan Nasional Terhadap Pemenuhan Rumah Layak Huni di Provinsi Riau}

Sebagaimana arahan Presiden RI, teks Rencana Pembangunan Jangka Menengah Nasional tahun 2020-2024 menyatakan bahwa terdapat lima (5) strategi pelaksanaan visi dan misi Nawacita termasuk pembangunan sumber daya manusia, pembangunan infrastruktur, penyederhanaan regulasi, penyederhanaan birokrasi dan transformasi ekonomi. Strategi terkait perumahan masuk dalam poin kedua (2) misi Nawacita yaitu meningkatkan jalur perumahan dan permukiman yang memadahi, aman, dan terjangkau.

Pemerintah melalui major project mengembangkan program Rumah Susun Perkotaan sebanyak 1 juta dengan maksud mengembangkan akses masyarakat terhadap perumahan layak dan aman yang terjangkau bagi sebagian besar rumah tangga perkotaan dan menanggulangi permukiman kumuh.

Catatan pemerintah terkait kondisi riil akses rumah layak huni di Indonesia, menyatakan bahwa persentase rumah tangga yang tinggal di Rumah Layak Huni mencapai 54,1\%, persentase rumah tangga yang mendapatkan akses sanitasi layak masih 74,6\% dan persentase rumah tangga yang memiliki akses air minum layak masih menginjak $87,8 \%$. Hal ini menunjukkan masih terdapat gap atau usaha yang diperlukan untuk mencapai akses global. Walaupun tingkat kepemilikan rumah di Indonesia sudah mencapai $80 \%$, tetapi masih terdapat $45,9 \%$ rumah tangga pada tahun 2018 yang menempati rumah tidak layak huni dan permukiman kumuh berdasarkan beberapa indikator teknis yang dinilai oleh Bappenas belum layak seperti ketahanan bangunan, luas lantai perkapita, dan saluran air minum juga sanitasi yang memadahi.

Permasalahan pada sisi permintaan adalah masih rendah akses pembiayaan perumahan bagi masyarakat berpenghasilan rendah termasuk masyarakat yang tidak memiliki penghasilan tetap dan ingin membangun rumah secara swadaya. Akses pada pembiayaan ini belum massif dan belum terfasilitasi di semua daerah hingga pelosok kecamatan.

Sementara permasalahan pada sisi pasokan adalah tersebarnya masyarakat di berbagai daerah bahkan pelosok permukiman hutan industri, Pulau-Pulau Terkecil dan Terluar (PKTT), perdesaan dan perkotaan pada umumnya. sehingga terbentuklah perkotaan yang berpencar (sprawl) dan juga menjalar mengikuti jaringan jalan yang dalam perencanaan penyediaan perumahannya juga kalah cepat dengan kebutuhan masyarakat.

Secara umum, pembangunan di wilayah provinsi Riau pada tahun 2020 sampai dengan 2020 untuk laju pertumbuhan ekonomi (LPE) ditarget akan mencapai 0,6\% - 1,5\%, akan tetapi dikarenakan pandemi COVID-19 berpengaruh pada semua bidang kehidupan, pada triwulan II tahun 2020 tertekan hingga ke level 2,7\% atau turun 1\% dari target yang diharapkan (BPS Riau, 2020). Sementara itu, tingkat kemiskinan yang ada pada tahun pencatatan di 2019 menunjukkan angka 7,08\% dan pada tahun 2020 menunjuk angka terkoreksi menjadi 6,90\% atau sejumlah 483,920 jiwa. Kemudian untuk tingkat pengangguran terbuka (TPT) sebesar $6 \%$ di tahun 2020, dan diharapkan dapat terus ditekan hingga $4,90 \%$ di tahun 2024. Menurut BPS Provinsi Riau TPT pada tahun 2020 di Triwulan II mencapai 5,07\%.

Provinsi Riau pada masa sekarang dan masa depan diharapkan tetap menjadi lokasi pengembangan kawasan strategis terutama keberadaan dari Kawasan Industri (KI) Tenayan dan Tanjung Buton. Sementara komoditas unggulan yang terus dipacu adalah sawit, karet, kelapa. Selain itu komoditas lain yang diharapkan dapat tumbuh adalah budidaya perikanan seperti komoditas ikan dan rumput laut. Sektor lain yang masih eksis dan terus didorong untuk memacu pertumbuhan ekonomi lokal ialah pengembangan pertambangan termasuk gas dan minyak bumi.

Sementara pengembangan kawasan perkotaan dan prasarananya, dengan adanya pengembangan kota baik besar, sedang ataupun kecil dengan infrastruktur yang terkoneksi seperti jaringan perpipaan gas bumi, jaringan Kereta Api Sumatera, Tol Trans Sumatera, Penyediaan Rumah Susun yang dialokasikan untuk Buruh, Pekerja dan Aparatur Sipil Negara, Sistem Pengelolaan Air Limbah Domestik atau SPALD skala kota di Pekanbaru, skala permukiman di Pekanbaru, dan Tempat Pembuangan Akhir (TPA) perkotaan terutama di Kota Dumai terus dipacu untuk mewujudkan kotakota yang layak huni.

Perhatian pemerintah juga tertuju pada penyediaan infrastruktur air baku untuk permukiman yang ada di PulauPulau Terkecil dan Terluar (PKTT) seperti Kabupaten Bengkalis dan Kabupaten Kepulauan Meranti. Program dukungan lain sebagai upaya untuk mewujudkan rumah yang layak adalah kepastian terhadap rasa aman berbentuk administratif/legal tanah dengan pengadaan sertifikat hak atas tanah dari Kementerian Agraria Tata Ruang/Badan Pertanahan Nasional pada program Sertifikat Hak Atas Tanah sebanyak 201.964 tersebar di Riau dan dukungan untuk melakukan pemeriksaan ulang penataan rencana tata ruang berbilang 14 penerapan rencana tata ruang.

Mencermati kebijakan pemerintah terhadap pemenuhan kebutuhan rumah layak huni di Provinsi Riau, terlihat bahwa Pemerintah hanya mampu mengintervensi masyarakat Riau hanya pada program perkotaan sebagaimana yang menjadi kewenangan pusat. Sementara kondisi geografis, tipologi dan pola persebaran permukiman di Riau menyebar hingga ke pelosok perkebunan bahkan hingga ke Pulau-Pulau Terkecil dan Terluar (PKTT). 


\section{B. Kebijakan Daerah Terhadap Pemenuhan Rumah Layak Huni}

Salah fokus urusan wajib pelayanan dasar yang menjadi muatan penting Rencana Pembangunan Jangka Menengah Daerah (RPJMD) Provinsi Riau adalah perumahan rakyat dan kawasan permukiman. Berdasarkan pendataan yang dilakukan oleh BKKBN di tahun 2016, setidaknya terdapat masyarakat miskin yang belum memiliki rumah sebanyak 314.692 rumah tangga. Perhatian pemerintah daerah difokuskan kepada kelompok tersebut sebagai upaya untuk menjawab kehadiran negara dalam menyeimbangkan pemenuhan layanan dasar bagi semua kelompok masyarakat.

Selain kelompok masyarakat miskin tersebut, pemerintah daerah juga memiliki permasalahan pemenuhan rumah layak huni terutama pada kelompok masyarakat non miskin dan atau masyarakat berpenghasilan rendah. Masyarakat berpenghasilan rendah di Provinsi Riau berdasarkan data yang PPDPP terdapat 464.622 unit/RT (2015). Sementara kemampuan pasokan dan daya serap terhadap hunian juga masih menjadi kendala terutama pada kawasan perkotaan Riau.

Tabel 1.

Jumlah Pembangunan RSLH Tahun 2009-2017 di Provinsi Riau

\begin{tabular}{clccccccc}
\hline \hline No. & $\begin{array}{l}\text { Kabupaten } \\
\text { / Kota }\end{array}$ & $\mathbf{2 0 0 9}$ & $\mathbf{2 0 1 0}$ & $\mathbf{2 0 1 1}$ & $\mathbf{2 0 1 2}$ & $\mathbf{2 0 1 3}$ & $\mathbf{2 0 1 7}$ & Jumlah \\
& $\begin{array}{l}\text { Kuantan } \\
1\end{array}$ & 80 & 60 & 30 & 24 & 78 & 165 & 437 \\
& $\begin{array}{l}\text { Singingi } \\
2\end{array}$ & & & & & & & \\
& Indragiri & 90 & 60 & 30 & 60 & 136 & 166 & 542 \\
& Hulu & & & & & & & \\
3 & Indragiri & 75 & 60 & 20 & 35 & 26 & 162 & 378 \\
& Hilir & & & & & & & \\
4 & Pelalawan & 55 & 80 & 30 & 30 & 39 & 160 & 394 \\
5 & Siak & 75 & 70 & 30 & 25 & 91 & 165 & 456 \\
6 & Kampar & 120 & 80 & 20 & 45 & 52 & 164 & 481 \\
7 & Rokan Hulu & 90 & 80 & 40 & 50 & 60 & 162 & 482 \\
8 & Bengkalis & 55 & 55 & 20 & 30 & 29 & 164 & 353 \\
9 & Rokan Hilir & 40 & 50 & 20 & 26 & 13 & 163 & 312 \\
10 & Kepulauan & 0 & 60 & 30 & 50 & 60 & 167 & 367 \\
& Meranti & & & & & & & \\
11 & Pekanbaru & 75 & 60 & 20 & 30 & 26 & 168 & 379 \\
12 & Dumai & 45 & 85 & 30 & 10 & 30 & 167 & 367 \\
& Jumlah & $\mathbf{8 0 0}$ & $\mathbf{8 0 0}$ & $\mathbf{3 2 0}$ & $\mathbf{4 1 5}$ & $\mathbf{6 4 0}$ & $\mathbf{1 . 9 7 3}$ & $\mathbf{4 . 9 4 8}$ \\
\hline \hline
\end{tabular}

\section{Analisis Proyeksi Penduduk}

Untuk menganalisis kependudukan, metode yang digunakan adalah pertumbuhan penduduk eksponensial. Metode ini digunakan peneliti sebab mengilustrasikan proses perkembangan penduduk yang terus berlanjut sesuai realitas yang ada di lapangan. Proyeksi penduduk dapat diketahui setelah mendapatkan nilai rata-rata pertumbuhan $(r)$ yang didapat dari analisis tingkat laju pertumbuhan penduduk.

Proyeksi penduduk di Provinsi Riau pada tahun 2039 sebesar 9.669.626 jiwa. Dimana Kota Pekanbaru merupakan wilayah dengan penduduk paling banyak yaitu sekitar 1.610.165 jiwa, kemudian diikuti oleh Kabupaten Kampar sekitar 1.207.370 jiwa dan Kabupaten Rokan Hulu sekitar 1.174.698 jiwa. Adapun wilayah dengan jumlah penduduk paling sedikit yaitu berada di Kabupaten Kepulauan Meranti sekitar 184.537 jiwa, Kabupaten Kuantan Singingi sekitar 352.785 jiwa dan Kota Dumai sekitar 399.980 jiwa sebagaimana terlihat pada Tabel 2 .
Tabel 2

Proyeksi Penduduk Riau Tahun 2029, Tahun 2034 dan Tahun 2039

\begin{tabular}{clcccc}
\hline \hline No. & Kabupaten / Kota & $\mathbf{2 0 2 4}$ & $\mathbf{2 0 2 9}$ & $\mathbf{2 0 3 4}$ & $\mathbf{2 0 3 9}$ \\
& & & & & \\
1 & Kuantan Singingi & 329.958 & 337.567 & 345.176 & 352.785 \\
2 & Indragiri Hulu & 470.474 & 503.486 & 536.498 & 569.510 \\
3 & Indragiri Hilir & 766.820 & 800.450 & 834.080 & 867.710 \\
4 & Pelalawan & 588.636 & 694.355 & 802.075 & 908.794 \\
5 & Siak & 543.041 & 599.254 & 655.468 & 711.681 \\
6 & Kampar & 949.966 & 1.035 .767 & 1.121 .569 & 1.207 .370 \\
7 & Rokan Hulu & 810.810 & 932.106 & 1.053 .402 & 1.174 .698 \\
8 & Bengkalis & 588.457 & 611.524 & 634.592 & 657.659 \\
9 & Rokan Hilir & 788.297 & 867.110 & 945.922 & 1.024 .735 \\
10 & Kepulauan Meranti & 182.995 & 183.509 & 184.023 & 184.537 \\
11 & Pekanbaru & 1.254 .346 & 1.372 .952 & 1.491 .559 & 1.610 .165 \\
12 & Dumai & 329.449 & 352.959 & 376.470 & 399.980 \\
& Jumlah & $\mathbf{7 . 6 0 3 . 2 4 9}$ & $\mathbf{8 . 2 9 1 . 0 3 9}$ & $\mathbf{8 . 9 8 0 . 8 3 4}$ & $\mathbf{9 . 6 6 9 . 6 2 4}$ \\
\hline \hline
\end{tabular}

\section{Analisis Perhitungan Backlog}

Backlog perumahan merupakan keadaan ketidakseimbangan antara kuantitas bangunan rumah yang ada dengan rumah yang diperlukan oleh rakyat [6]. Dari penguraian diatas, Backlog perumahan adalah kuantitas rumah yang belum/tidak terurus. Backlog perumahan dihitung menurut rencana bahwa satu rumah tangga atau kepala keluargahanya membutuhkan satu rumah.

Dalam memastikan kuantitas Backlog perumahan, terdapat perbedaan sudut pandang (perspektif) terhadap Backlog atau kekurangan rumah antara perspektif Kementerian PUPR dengan perspektif BPS. Backlog rumah itu terhadap rumah yang tidak layak huni menurut Kementerian PUPR, sementara itu BPS berpendapat, Backlog rumah itu atas rumah milik. Menurut BPS, masyarakat (rumah tangga) berdiam di rumah yang layak huni, tapi sewa, tetap dianggap Backlog perumahan. Sebaliknya menurut perspektif Kementerian PUPR, sepanjang sudah tinggal di hunian yang layak, maka tidak terhitung sebagai angka Backlog perumahan. Dengan adanya perbedaan tersebut, kecenderungan angka Backlog perumahan Kementerian PUPR lebih kecil dari Backlog BPS.

Skenario penyediaan perumahan di Provinsi Riau sampai dengan tahun 2039 atau empat (4) kali masa RPJMD dan/atau rentang 20 tahun mendatang dapat dilaksanakan dengan berbagai program kegiatan, sesuai kewenangan sebagaimana telah diatur dalam UU No 11 Tahun 2009, UU No 29 Tahun 2009, UU No 1 Tahun 2011, UU No 13 Tahun 2011, UU No 20 Tahun 2011, UU No 23 Tahun 2014, dan Peraturan Pemerintah Nomor 2 Tahun 2018 dan lainnya. Kolaborasi antar pemerintah dan masyarakat perlu terus dilaksanakan agar tingkat kesejahteraan masyarakat terutama kelompok masyarakat yang memerlukan bantuan dari pemerintah dapat mengakses rumah layak huni sebagaimana pada Tabel 3.

$$
\text { Tabel } 3 .
$$

Kebijakan Penanganan Perumahan dan Kawasan Permukiman dan Kelompok

\begin{tabular}{clcl}
\multicolumn{3}{c}{ Masyarakat di Provinsi Riau } \\
\hline \hline No & \multicolumn{1}{c}{ Kelompok } & \multicolumn{1}{c}{ Kebijakan } & Jumlah di Riau \\
& Masyarakat & & \\
Masyarakat & Undang-undang & $10 \%-40 \%$ dari Jumlah \\
& Berpenghasilan & Nomor 1 Tahun & Penduduk/Rumah Tangga Riau \\
& Tinggi dan & 2011, Undang- & \\
& Menengah & undang Nomor 20 & \\
& & Tahun 2011 & \\
2 & Terkena Bencana & Undang-undang & Rerata 304 Unit/Tahun \\
& dan Terkena & Nomor 23 Tahun & \\
& Program & 2014, Peraturan & \\
& Pemerintah & Pemerintah Nomor & \\
& (Pusat/Daerah) & 2 Tahun 2018 & \\
\hline \hline
\end{tabular}




\begin{tabular}{clll}
\hline \hline 3 & Rumah Tangga & Undang-undang & 314.692 rumah tangga miskin \\
& Miskin (RTM) & Nomor 23 Tahun \\
& & \\
& & \\
& Daerah Provinsi \\
& Riau Nomor 16 & \\
& & Tahun 2018 \\
& & Undang-undang & 163.739 Rumah Tangga (2018), \\
4 & Masyarakat & Nomor 1 Tahun & 477.900 Rumah Tangga (2020), \\
& Berpenghasilan & 2011, Undang- & 515241 Rumah Tangga (2024), \\
& Rendah (MBR) & undang Nomor 20 & 561.918 Rumah Tangga (2034), \\
& Formal & Tahun 2011 & 655.271 Rumah Tangga (2039) \\
& & (Kewenangan Pusat) \\
5 & Transmigrasi & Undang-undang & Rerata 60 Kepala Keluarga \\
& & Nomor 29 Tahun & \\
& & 2009 & \\
6 & Fakir Miskin & Undang-undang & 303.438 orang \\
& & Nomor 13 Tahun & \\
& & 2011 & \\
\hline \hline
\end{tabular}

Untuk pemerintah daerah, seperti yang tertuang dalam UU No 23 Tahun 2014 dan UU No 1 Tahun 2011 serta kebijakan terkait lainnya, program pengembangan perumahan yang dapat dilakukan dapat berupa Bantuan Stimulan Perumahan Swadaya (BSPS) baik itu Peningkatan Kualitas (PK) \& Pembangunan Baru (PB), Penyediaan Rumah bagi masyarakat terkena Program Pemerintah Daerah dan terkena akibat bencana.

Dalam melakukan proyeksi, analisisnya menggunakan dua versi data yaitu BPS dan BKKBN. Berdasarkan hasil proyeksi di tahun 2020 menggunakan data BPS, proyeksi Backlog akan mencapai 447.900 rumah tangga, tahun 2024 Backlog diproyeksikan mencapai 515.240 rumah tangga, tahun 2029 Backlog diproyeksikan mencapai 655.271 rumah tangga, tahun 2034 Backlog diproyeksikan mencapai 608.595 rumah tangga dan tahun 2039 Backlog diproyeksikan mencapai 655.271 rumah tangga seperti yang terdapat pada Tabel 4 .

$$
\text { Tabel } 4 .
$$

Proyeksi Backlog Kepemilikan Rumah di Riau Tahun 2029, Tahun 2034 dan Tahun 2039 - BPS Riau, 2019

\begin{tabular}{|c|c|c|c|c|c|c|}
\hline No & Kabupaten/Kota & T2019 & T2024 & T2029 & T2034 & T2039 \\
\hline 1 & Kuantan Singingi & 21.844 & 22.360 & 22.876 & 23.391 & 23.907 \\
\hline 2 & Indragiri Hulu & 29.645 & 31.882 & 34.119 & 36.356 & 38.593 \\
\hline 3 & Indragiri Hilir & 49.685 & 51.964 & 54.243 & 56.522 & 58.801 \\
\hline 4 & Pelalawan & 32.658 & 39.889 & 47.121 & 54.353 & 61.585 \\
\hline 5 & Siak & 32.990 & 36.800 & 40.609 & 44.418 & 48.228 \\
\hline 6 & Kampar & 58.561 & 64.375 & 70.190 & 76.004 & 81.819 \\
\hline 7 & Rokan Hulu & 46.726 & 54.945 & 63.165 & 71.385 & 79.605 \\
\hline 8 & Bengkalis & 38.314 & 39.877 & 41.441 & 43.004 & 44.567 \\
\hline 9 & $\begin{array}{l}\text { Rokan Hilir } \\
\text { Kepulauan }\end{array}$ & 48.079 & 53.420 & 58.761 & 64.101 & 69.442 \\
\hline 10 & Meranti & 12.366 & 12.401 & 12.436 & 12.471 & 12.505 \\
\hline 11 & Pekanbaru & 76.964 & 85.002 & 93.039 & 101.077 & 109.114 \\
\hline 12 & Dumai & 20.732 & 22.325 & 23.919 & 25.512 & 27.105 \\
\hline & Riau & 468.565 & 515.241 & 561.918 & 608.595 & 655.271 \\
\hline
\end{tabular}

Skenario penanganan Backlog dapat dilakukan dengan berbagai cara, namun target kelompok sasaran dan kepastian ketepatan sasaran penanganan menjadi faktor penting dalam penyediaan perumahan. Jika mencermati data yang diterbitkan oleh Dinas Penanaman Modal dan Pelayanan Terpadu Satu
Pintu (DPMPTSP) Se-Provinsi Riau pada tahun 2017, Izin Mendirikan Bangunan (IMB) yang diterbitkan oleh seluruh kabupaten kota sebesar 31.369 unit rumah subsidi dan 6.170 unit komersil maka dapat disimpulkan bahwa data tersebut merupakan kinerja terbaik yang ada saat ini. Namun, jika disandingkan pada prediksi Backlog yang terjadi di Kabupaten/Kota di Riau maka kinerja tersebut masih jauh dari harapan yang terdapat pada Gambar 2.

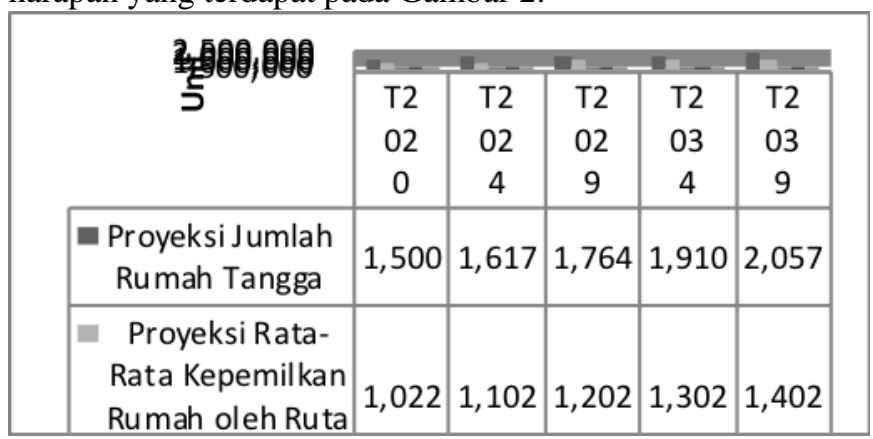

Gambar 1. Skenario Penanganan Backlog Kepemilikan Rumah.

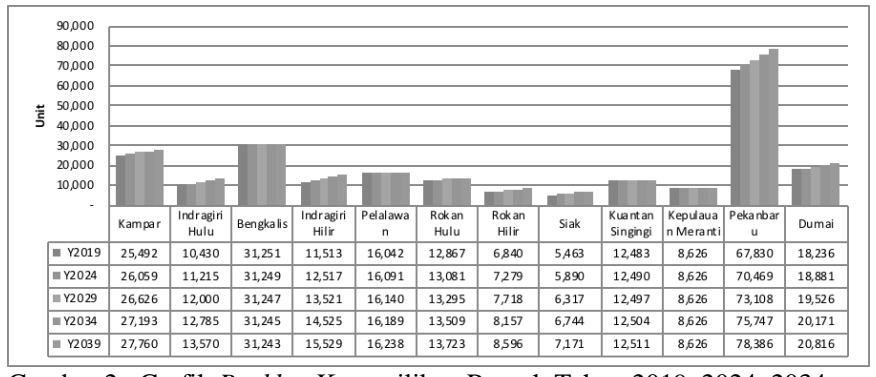

Gambar 2. Grafik Backlog Kepemilikan Rumah Tahun 2019, 2024, 2034,

2039 di Provinsi Riau - BKKBN Riau, 2019

Sementara itu untuk proyeksi Backlog berdasarkan data BKKBN jumlah data Backlog kepemilikan rumah di tahun T22018 telah mencapai 229.802 unit, dimana pada tahun 24.sebelumnya berjumlah 218.138 unit dan di tahun 2015 40.83rjumlah 218.172 unit. Selanjutnya dengan menggunakan pola data tersebut, dilakukan proyeksi hingga 2039 maka 61. didapatkan bahwa angka Backlog kepemilikan rumah di 68.Provinsi Riau akan mencapai 254.169 unit. Angka ini juga 52. Ujbih kecil dari yang ditetapkan oleh Pemerintah Provinsi yaitu terdapat Rumah Tangga Miskin (RTM) sebanyak 87.6334.692 di tahun 2016 (Badan Kependudukan dan Keluarga 87.Berencana Nasional, 2016). Pemerintah Provinsi memandang 46.93hwa data ini relevan dengan jumlah tingkat kemiskinan yang ada di Provinsi Riau.

${ }^{74.783}$ Berdasarkan hasil proyeksi, maka terlihat bahwa seluruh 12.k4bupaten dan kota yang ada di Provinsi Riau akan mengalami 11 keskurangan rumah. Kabupaten Kampar pada tahun 2019 kekurangan rumah sebanyak 25.492 unit dan rerata rumah per 28. 198 ma tahunan sebesar 567 unit kekurangan rumah. Kabupaten 70 Inedragiri Hilir pada tahun 2019 mengalami kekurangan rumah sebanyak 11.513 unit dengan rerata kekurangan rumah per lima tahunan sebesar 1004 unit. Kota Pekanbaru mengalami kekurangan rumah sebanyak 67.830 unit pada tahun 2019 dan pada tahun 2039 akan mengalami defisit rumah sebanyak 78.386 unit - dengan arti rerata defisit tahunan sebanyak 2.639 unit. 
Selanjutnya dengan menggunakan data rekapitulasi pembangunan perumahan bagi Masyarakat Berpenghasilan Rendah (MBR) dari DPMPTSP Provinsi Riau, dan data dari Program Perbaikan dan Pembangunan RTLH oleh Pemerintah Provinsi Riau melalui Peraturan Gubernur Riau Nomor 21 Tahun 2019 maka kebutuhan dan/atau kekurangan rumah masih sangat besar yakni pada tahun 2039 akan mencapai 224.169 unit.

Mencermati pola data, analisis, dan kemampuan pemerintah, masyarakat dan pengembang dalam penyediaan rumah yang layak, terlihat masih jauh dari harapan. Artinya, program pemerintah baik pusat dan daerah perlu secara menerus untuk dilaksanakan terutama bagi masyarakat Rumah Tangga Miskin (RTM) dan Masyarakat Berpenghasilan Rendah (MBR).

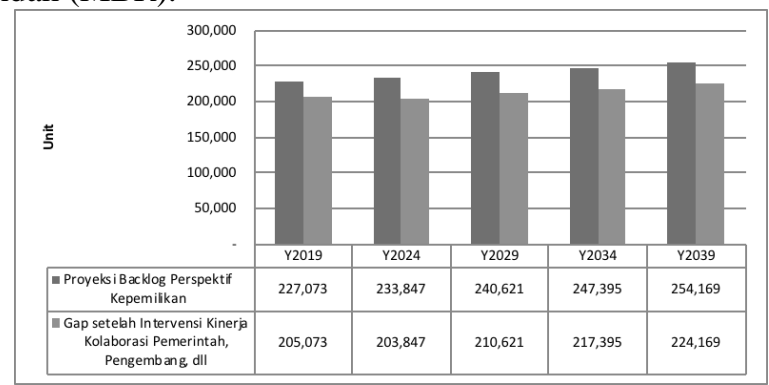

Gambar 3. Grafik Proyeksi Backlog Kepemilikan Rumah Setelah di Intervensi Tahun 2019, 2024, 2034, 2039 di Provinsi Riau.

\section{E. Analisis berbasis GIS untuk Lokasi Perumahan pada Kawasan Fungsi Lain Yang Perlu Penanganan Khusus}

Provinsi Riau merupakan salah satu dari banyaknya Provinsi yang ada di Indonesia yang mengalami persoalan tentang permukiman yang berada di Kawasan Non Perumahan dan Kawasan Permukiman (PKP). Dahulu masalah ini dikenal dengan Holding Zone yaitu kawasan dalam tata ruang wilayah yang belum dibebankan izin. Dengan terbitnya Peraturan Daerah Nomor 10 Tahun 2018 tentang Rencana Tata Ruang Wilayah Provinsi Riau, pemerintah provinsi telah menetapkan norma baru terhadap permukiman yang berada di kawasan non permukiman.

Menurut Rencana Tata Ruang Wilayah (RTRW) Provinsi Riau tersebut, terdapat dua klasifikasi lokasi permukiman yang berada diluar Kawasan Permukiman berdasarkan pola dan struktur ruangnya, yaitu Outlined dan Negative List. Outlined adalah delineasi rencana kawasan hutan untuk kepentingan di luar kegiatan kehutanan yang digambarkan pada peta rencana pola ruang Rencana Tata Ruang Wilayah (RTRW) Provinsi Riau. Sedangkan negative list adalah lokasi-lokasi larangan untuk dibangun perumahan dan permukiman seperti di kawasan hutan lindung, hutan konservasi, sempadan sungai, dan kawasan hutan produksi terbatas.

Berdasarkan analisis dengan menggunakan pendekatan Geographic Information System (GIS), dan dengan menggunakan data draf rencana tata ruang wilayah masingmasing kabupaten/kota terdapat beberapa kampung/desa yang berada di kawasan negative list permukiman. Kawasan negative list permukiman adalah pusat kawasan permukiman
(PKP) yang berada di zona lindung seperti sempadan sungai, sempadan pantai, hutan lindung (HL), dan kawasan hutan produksi terbatas (HPT) sebagaimana terlihat pada Tabel 5.

Tabel 5.

Hunian Yang Berada di Non Fungsi Permukiman

\begin{tabular}{llccccc}
\hline \hline No & Kabupaten/Kota & $\begin{array}{c}\text { Hutan } \\
\text { Lindung }\end{array}$ & $\begin{array}{c}\text { Hutan } \\
\text { Produksi }\end{array}$ & Gambut & $\begin{array}{c}\text { Sempadan } \\
\text { Sungai }\end{array}$ & $\begin{array}{c}\text { Garis } \\
\text { Pantai }\end{array}$ \\
1 & Kab. Kepulauan & - & 12 & 21 & 1 & 20 \\
& Meranti & - & 12 & 56 & 28 & 101 \\
2 & Kab. Rokan Hulu & - & 2 & 49 & 44 & 8 \\
3 & Kab. Siak & 2 & 7 & 14 & 11 & 13 \\
4 & Kota Dumai & - & - & 8 & 21 & 83 \\
5 & Kota Pekanbaru & & & & & \\
\hline \hline
\end{tabular}

Dari tabel tersebut tergambar bahwa permukiman yang dibangun di kawasan negative list garis pantai di Kabupaten Rokan Hulu (101 unit) dan Kota Pekanbaru (83 unit) paling mencemaskan. Berikutnya adalah permukiman yang dibangun di lahan gambut sebanyak 56 unit di Kabupaten Rokan Hulu dan 49 unit di Kabupaten Siak. Selain itu terdapat permukiman di sempadan sungai di Kabupaten Siak (44 unit), Kabupaten Rokan Hulu (28 unit), dan Kota Pekanbaru (21 unit). Masyarakat yang tinggal di sempadan pantai dan sempadan sungai sangat berbahaya karena selain rawan bencana juga berpotensi menjadi kawasan permukiman kumuh yang mendegradasi kualitas hidup penghuninya. Sedangkan masyarakat yang tinggal di atas lahan gambut terancam bahaya kebakaran meskipun lahan gambut merupakan tangkapan air (catchment area). Untuk hunian di atas lahan hutan lindung dan hutan produksi yang masih berstatus tanah ulayat masih ada potensi untuk diberikan izin tinggal, menjaga hutan dan mengusahakan tanahnya sesuai ketentuan Undangundang Pokok Agraria (UUPA). Diluar hunian, dalam rangka pengentasan kemiskinan, masyarakat yang mata pencahariannya tergantung pada kawasan hutan berpeluang untuk mendapatkan hak atas tanah dari hasil pelepasan kawasan hutan tersebut dengan sejumlah ketentuan sebagaimana diatur dalam Peraturan Presiden Nomor 86 Tahun 2018 tentang Reforma Agraria.

Berdasarkan Rencana Pembangunan Jangka Menengah Daerah (RPJMD) Tahun 2020-2024 terdapat 30 lokasi abrasi yang membawa kerusakan pada prasarana, sarana dan utilitas serta perumahan sehingga perlu mendapat perhatian dari pemerintah provinsi dan kabupaten/kota. Pemerintah provinsi perlu memprioritaskan pusat kawasan permukiman (PKP) yang berada di kawasan bukan pusat kawasan permukiman (PKP) terutama yang memiliki indikasi berpotensi bencana, miskin dan kumuh. Sesuai dengan amanat Peraturan Pemerintah Nomor 2 Tahun 2018, Peraturan Menteri Dalam Negeri Nomor 100 Tahun 2018 dan Peraturan Menteri Pekerjaan Umum dan Penataan Ruang Nomor 29 Tahun 2018 serta Peraturan Menteri Dalam Negeri Nomor 90 Tahun 2019 telah mengamanatkan pemerintah provinsi dan pemerintah daerah untuk melakukan pendataan perumahan dan kawasan permukiman yang berada pada daerah bencana dan menyiapkan lahan relokasi melalui pengadaan lahan perumahan. 


\section{KESIMPULAN}

Banyaknya masyarakat miskin dan belum memiliki rumah layak huni di Provinsi Riau harus mendapat perhatian pemerintah daerah melalui dukungan peraturan daerah dan anggaran dalam Anggaran Pendapatan dan Belanja Daerah (APBD). Melalui program yang telah dukung oleh peraturan daerah (perda) dan keberpihakan melalui penganggaran (APBD Provinsi) seluruh masyarakat miskin yang belum memiliki rumah akhirnya mendapatkan rumah sederhana layak huni, sementara rumah masyarakat miskin yang buruk kualitasnya diperbaiki menjadi layak huni.

Selain itu, keberpihakan dan kehadiran pemerintah provinsi juga hadir dalam pelaksanaan program rumah sederhana layak huni (RSLH) dan perbaikan infrastruktur perumahan pada perumahan dan permukiman yang berada pada kawasan non hunian seperti yang berada di hutan lindung, hutan produksi, gambut, sempadan sungai serta yang berada di garis pantai.

\section{REKOMENDASI}

Terbatasnya data primer bergradual terkait jumlah rumah tangga miskin (RTM) bertempat rumah tidak layak huni (RTLH) pada instansi pemerintah daerah, baik itu BPS Provinsi Riau dan BKKBN Provinsi Riau, maka diperlukan pendataan atau monitoring dan evaluasi yang secara menerus (berkelanjutan) sehingga data selalu terbarukan.

Sementara data kependudukan dan kepemilikan (penguasaan) rumah sudah layak dijadikan acuan dengan time series sejak 2013-2019 (7 Tahun) dari BPS Provinsi Riau.

Adapun strategi penanganan backlog kepemilikan dan kepenghunian yang dapat dilakukan secara menerus oleh Pemerintah Daerah adalah melaksanakan pembangunan RSLH bagi RTM yang belum ditangani atau masuk dalam pendataan Pemda. Sementara untuk masyarakat berpenghasilan rendah (MBR), Pemerintah Daerah, Pusat (Kementerian PUPR), Pengembang dan Perbankan terus berkolaborasi mengejar ketertinggalan penyediaan hunian baru terutama di Kawasan Perkotaan Riau.

Selanjutnya bagi masyarakat menengah yang mampu secara swadaya menyediakan huniannya, diperlukan peran Pemerintah Daerah dalam melakukan pembinaan mulai dari tahap perencanaan, pembangunan dan pemanfaatan huniannya.

\section{DAFTAR PUSTAKA}

[1] Firdaus, "Pemenuhan Hak Atas Perumahan Yang Layak Bagi Masyarakat Miskin Kota Dalam Perspektif HAM", Jurnal Penelitian HAM, Vol. 7 (2016, Des) 85-97.

[2] Badan Pusat Statistik, "Provinsi Riau Dalam Angka 2019. Diakses dari:https://riau.bps.go.id/publication/2019/08/16/5e5d413e881e6f3ec18 3f634/provinsi-riau-dalam-angka-2019.html

[3] Purba, TP, Topan Himawan, Ernamayanti, Nur Irfan Ashari, "Strategi Pembangunan dan Pengembangan Perumahan dan Kawasan Permukiman Provinsi Banten, ISSN: (P) 2615-2584, ISSN: (E) 26153343, diakses dari: https://trijurnal.lemlit.trisakti.ac.id/pakar/article/view/2639

[4] Muhtadi, Tb Yudi,"Implementasi Kebijakan Program Penyediaan Rumah Layak Huni Bagi Masyarakat Berpenghasilan Rendah di Kota Tangerang”, Jurnal Pelita, Vol. 20 (2020, Feb) P-ISSN: 1907-5693 EISSN: 2684-8856 diakses dari: http://ejournal.unis.ac.id/index.php/pelita/article/download/821/630.
[5] Winarno, B. (2018). Skema Penyediaan Rumah Layak Huni bagi Masyarakat Miskin di Kabupaten Belitung. Jurnal Pengembangan Kota. Vol 6 (1): 66-74. DOI: 10.14710/jpk.6.1.66-74.

[6] Kementerian Keuangan, "Peranan APBN Dalam Mengatasi Backlog Perumahan Bagi Masyarakat Berpenghasilan Rendah (MBR)", diakses dari: http://www.anggaran.kemenkeu.go.id/api/Medias/d5d98b36-3ed8$4 \mathrm{~b} 9 \mathrm{f}-9 \mathrm{~d} 95-$

b95a6e8878cf\#: :text=Secara\%20umum\%20backlog\%20perumahan $\% 2$ Odapat,rumah\%20yang\%20belum\%2Ftidak\%20tertangani.

[7] Rosa, Yulinda,"Rumusan Metode Perhitungan Backlog Rumah", Jurnal Permukiman, Vol. 08 (2013, Feb) P-ISSN: 1907-5693 E-ISSN: 19074352 diakses

http://jurnalpermukiman.pu.go.id/index.php/JP/article/view/87/74.

[8] Undang-undang Nomor 1 Tahun 2011 tentang Perumahan dan Kawasan Permukiman

[9] Peraturan Pemerintah Nomor 2 Tahun 2018 tentang Standar Pelayanan Minimal

[10] Peraturan Menteri Dalam Negeri Nomor 100 Tahun 2018 tentang Penerapan Standar Pelayanan Minimal

[11] Peraturan Menteri Pekerjaan Umum dan Perumahan Rakyat Nomor 29 Tahun 2018 tentang Standar Teknis Standar Pelayanan Minimal Pekerjaan Umum dan Perumahan Rakyat

[12] Peraturan Menteri Dalam Negeri Nomor 90 Tahun 2019 tentang Klasifikasi, Kodefikasi, dan Nomenklatur Perencanaan Pembangunan dan Keuangan Daerah 